\title{
An approach of historical and economic BRICS creation in South-South Cooperation resurgence landmark in the twenty-first century
}

Una aproximación histórica y económica de la creación de los BRICS en el marco del resurgimiento de la Cooperación Sur-Sur en el siglo XXI

Uma abordagem histórica-econômica da criação do BRICS no marco do ressurgimento da Cooperação Sul-Sul no século XXI

Gabriel Galdino ${ }^{1}$

DOI: $10.5752 /$ P.1809-6182.2020v17n3p73

Received in: June 03, 2020 Accepted in: November 02, 2020

\begin{abstract}
In the history of international relations, the association between developing countries occurred on a reduced scale until the mid-twentieth century. This article takes a historical and economic approach about the formation of the movements characterized as SouthSouth Cooperation, including the emergence of the BRICS in the 21st century. Keywords: BRICS. Economic Development. International Relations. South-South Cooperation.

\section{Resumen}

En la historia de las relaciones internacionales, la asociación entre paises en desarrollo se produjo en una escala reducida hasta mediados del siglo XX. Este artículo tiene un enfoque histórico y económico sobre la formación de los movimientos de Cooperación Sur-Sur, incluyendo el surgimiento de los BRICS.

Palabras clave: Cooperación Sur-Sur. BRICS. Desarrollo Economico. Relaciones Internacionales.
\end{abstract}

\section{Resumo}

$\mathrm{Na}$ história das relaçóes internacionais, a associação entre os países em desenvolvimento se deu em escala reduzida até a metade do século XX. Esse trabalho se insere numa abordagem histórica e econômica acerca da formação dos movimentos caracterizados como de Cooperação Sul-Sul, compreendendo o surgimento do BRICS no século XXI.

Palavras-chave: Cooperação Sul-Sul. BRICS. Desenvolvimento Econômico. Relaçôes Internacionais.

\footnotetext{
1 Master's Degree student (Postgraduate studies in Latin American Integration - PROLAM). University of São Paulo (USP): São Paulo, Brazil. ORCID iD: 0000-0003-0196-016. Email: galdinogabriel@usp.br
} 


\section{Introduction}

From the perspective of the international economy, it is clear that the different countries have been connected by a financial sys$t^{2} \mathrm{~m}^{2}$ that has been restructuring over time, to the detriment of the prevailing economic ideals among the major economies. The international system, by this bias, implies the concentration and maintenance of the interests of central regions to the detriment of peripheral regions, with minimal participation of the latter in the production of world changes. For this, it can be seen that historically the relations between the "developing countries" occurred on a small scale until the middle of the twentieth century.

From this period, what is called South-South Cooperation arises from the reflection of the interactions between these peripheral countries, which demanded policies of economic and social equity after the Second World War. Thus, a critical view of these nations in relation to the marginalization of their economies within the world political-economic system is evident. This perspective has crystallized into the creation of a development agenda within the UN through the United Nations Conference on Trade and Development (UNCTAD) ${ }^{3}$, driven by a series of events and conferences that converge in the formulation of multilateral

\footnotetext{
2 According to Eichengreen (2002), this system is established with the purpose of giving order and stability to foreign exchange markets, promoting the elimination of balance of payments problems and stimulating access to international credit in crisis situations.

3 In the context of the Bandung Conference in the early 1960s, after the Cairo Conference on "Problems of Economic Development", the United Nations Conference on Trade and Development (UNCTAD) is created.
}

mechanisms for technical and economic cooperation.

However, the emergence of neoliberalism as a reaction of the United States to the international economic crisis of the 1970s destabilizes this attempt to change the world status quo. Reflecting neoliberal policies in developing countries, the economic recession of the 1990s contextualizes the period in which the process of consolidation of South-South Cooperation is stagnant. In the early 2000s, once the perception of these countries changed with the parsimony of neoliberal development policies, along with the rise of progressive governments, the return of criticism of asymmetric globalization, and the focus of economic growth in countries such as China, Brazil, India and Russia show a new scenario of strengthening South-South relations and the emergence of coalitions of countries with emphasis on development cooperation.

Therefore, this article has as its general objective to provide a theoretical and historical approach to the international panorama in which the Third World conforms, its decline and the emergence of the BRICS. Using the qualitative analysis method with primary and secondary data, a linear analysis of the three conformation periods of South-South Cooperation is evidenced. Through a perspective of the international economy in whi$\mathrm{ch}$ it is proposed to characterize the economic asymmetry and its imposition by liberal and neoliberal currents. This will be complemented by Uneven and Combined Development (or unequal and combined development or uneven development) which explains how the economies of developing countries and those of developed countries integrate. 


\section{The international economic asymmetry: the theory of unequal and combined development and the emergency of the third world}

According to Amin (2004), the United States (USA) after World War II was already in a privileged position to exercise its economic hegemony in the international scenario. After World War II, during the Cold War, the capitalist economy experienced its "golden age" under US hegemony among the other economic powers. In line with Fiori (2004), international regimes and institutions formed the basis for a global management under the tutelage of the United States, so this period of "world hegemony" lasts for two decades until accentuating bipolarity in the international scenario.

The international system of this time, in its economic aspect, was characterized by a polarization, which was inherent in the process of capitalist globalization itself. In this sense, world capitalism was the engine of this polarization, generating the uneven development that is considered one of its insurmountable contradictions in view of its logic of constituting a true global market. Accumulation and expropriation are pertinent to this process (AMIN, 2009).

\footnotetext{
'Really existing' historical capitalism is associated with successive forms of accumulation by dispossession, not only at the origin ('primitive accumulation') but at all stages of its deployment. Once constituted, this 'Atlantic' capitalism set out to conquer the world and reshape it on the basis of the continuing dispossession of the conquered regions, thereby becoming the dominated peripheries of the system. (AMIN, 2009, p. 1).
}

The notion of unequal development has a remote origin, according to Theis (2009). Lenin coined the term by analyzing the develo- pment process of capitalism in Russia from a perspective of socioeconomic inequality. After the Revolution of 1905, influenced by Trotsky (1932), the term takes on a more precise meaning and is referred to as uneven and combined development, referring to political issues beyond the economic dimension.

Thus, the theory of uneven and combined development is an attempt to understand the capitalist transformations of the international scenario, and by attempting to respond to their economic and social contradictions, specifically of peripheral countries. With the rise of capitalism as an international economic system, world history becomes contradictory and therefore the conditions of economic and social development undergo a qualitative change (LÖWY, 1995).

The laws of history have nothing in common with a pedantic schematism. Unevenness, the most general law of the historic process, reveals itself most sharply and complexly in the destiny of the backward countries. Under the whip of external necessity their backward culture is compelled to make leaps. From the universal law of unevenness thus derives another law which, for the lack of a better name, we may call the law of combined development - by which we mean a drawing together of the different stages of the journey, a combining of the separate steps, an amalgam of archaic with more contemporary forms. Without this law, to be taken of course, in its whole material content, it is impossible to understand the history of Russia, and indeed of any country of the second, third or tenth cultural class. (TROTSKY, 1932, p. 15-16).

It is understood, therefore, that the least developed countries are constrained to adopt certain advanced features of the capitalist system of production, and intermediate stages of development are skipped. These countries have development through an original combination 
of the various forms of production that give rise to irregularities and complexities in their economic formation.

In this context, the Soviet Union as an important economic and political power in the international Cold War scenario leads the prospect of uneven and combined development to spread and then be used to analyze the economic insertion of the other peripheral countries, called at that time the Third World.

Figura 1 - The Third World (1952)

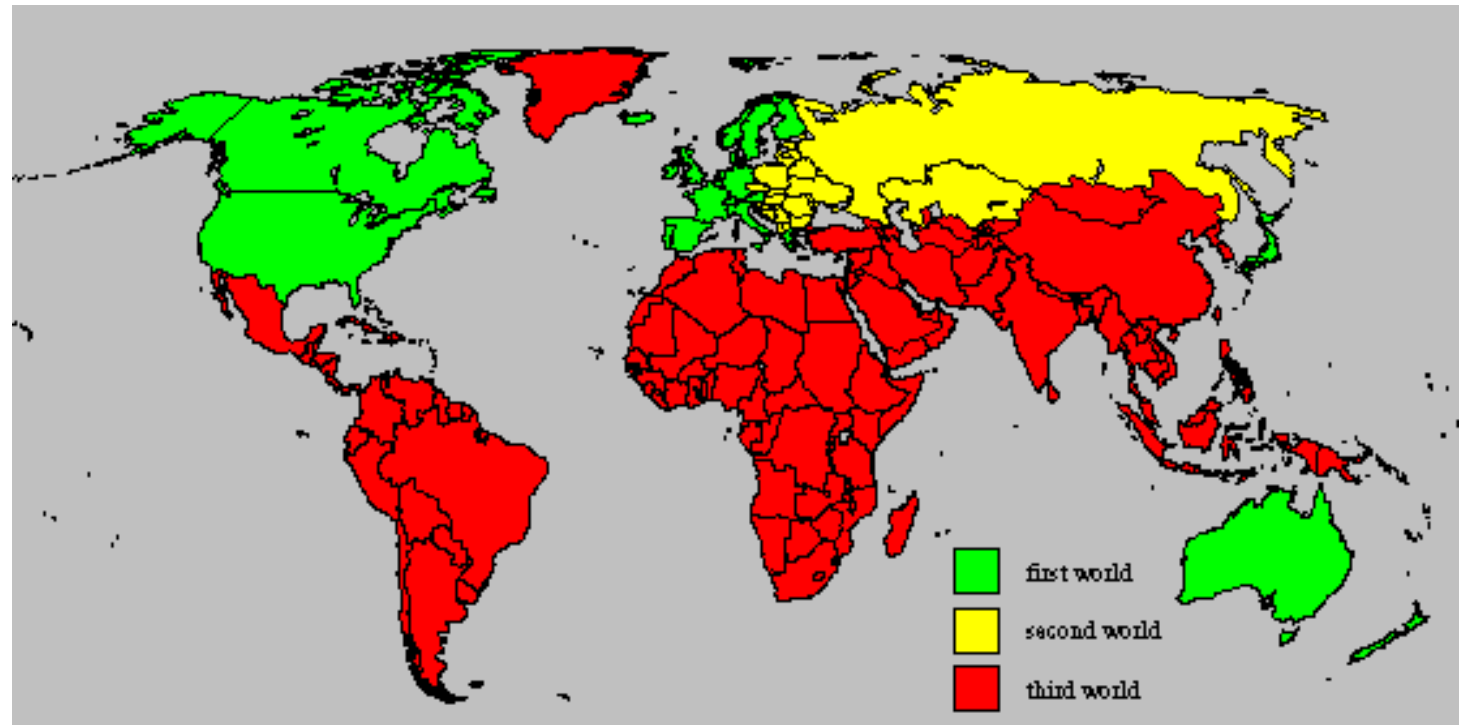

Fonte: University of Wisconsin-Eau Claire (UWEC, 2016).

As an expression that spread during the Cold War period and is related to this logic of asymmetric globalization, the Third World, a term coined by the French demographer Alfred Sauvy (1952), referred to countries that were not part of the select group of developed capitalist economies. (First World) and neither of the former socialist countries (Second World). After the Cold War, however, classifications such as "developing countries", "emerging countries", "southern countries" are then commonly employed in view of the vagueness of the term Third World in explaining aspects of contemporary reality.

The term "Third World" was used frequently in histories of the societies, economies and cultures of many parts of the world in the second half of the twentieth century. But, although the phrase was widely used, it was never clear whether it was a clear category of analysis or simply convenient and rather vague label for an imprecise collection of states in the second half of the twentieth century and some of the common problems that they faced. Not even enthusiasts for the term provided any precision. (TOMLINSON, 2003, p. 307).

In the Cold War environment, Third World Asian and African countries have challenged the bipolar structure in order to find an alternative to solving their political and economic problems without necessarily being linked to the ideology of capitalism or socialism. This movement culminates then at the Bandung Conference in 1955. In order to discuss the future of countries in the process of decolonization, the Bandung Conference highlights the issue of development as a theme for international politics, leaving aside the East-West Cold War focus (KOCHER, 2008). Therefore, a new moment of world history is inaugurated 
as the developing countries start to organize themselves in terms of common principles and ideas that were the foundation for the formulation of their strategies for the development of South-South relations.

Consequently, Bandung promote the North-South debate that represented the division between industrialized countries and primary product exporting countries, bringing together African and Asian states to defend an alternative system to bipolarity, thus sowing a proposal that would in future be conceived as multipolarity. Initially, according to Amin (2010), India and China were the countries that led this Southern movement. However, this third-world leadership role by China and India underwent profound changes in the 1970s, as the international economic crisis and friction between US and USSR now influence foreign policy in developing countries.

\section{Preludes of South-South Cooperation: consolidation of a Third World agenda}

The thought that developing countries identify certain common interests and problems and articulate themselves in order to solve them, according to Lima (2005), is the essential notion of the concept of South-South Cooperation (SSC). That is, these countries choose to cooperate with each other in order to mitigate the asymmetrical distribution of power and thereby achieve economic development on an autonomous basis, undermining any form of dependency. Acting in isolation, these states would end up with less satisfactory results compared to their political cooperation and coordination. In this sense, SSC becomes an important element of international development cooperation.

\begin{abstract}
South-South cooperation is a manifestation of solidarity among peoples and countries of the South that contributes to their national well-being, their national and collective self-reliance and the attainment of internationally agreed development goals [...] (UNOSSC, 2016, s/p).
\end{abstract}

Preludes of South-South Cooperation, with the development of Bandung's "neutralist" ideal by peripheral countries, results in the "Non-Aligned Movement" and, subsequently, with the accession of Latin American countries in Group 77 United Nations Conference on Trade and Development. The Third World ensemble that formed a new alliance of the South, the "Global South".

Providing mechanisms for the countries of the South to articulate and promote their economic interests was the main objective of the G-77. It was then aimed within the United Nations to establish joint negotiating capacity. Thus, the creation of the G-77 in 1964 represents the capacity for influence and political weight that "developing countries would exercise at the UN level, pushing for a new international economic order that was more just and egalitarian" (PEREIRA; MEDEIROS, 2015, p. 10). Henceforth the emergence of the UN-linked G-77 is the 1967 Algerian Charter, which becomes a symbol of the group's claim to mitigate economic inequality between countries. In the third part of the letter the group makes clear that this inequality is the responsibility of the entire international community:

The international community has an obligation to rectify these unfavorable trends and to create conditions under which all nations can enjoy economic and social well-being, and have the means to develop their respective resources to enable their peoples to lead a life free from want and fear. In a world of increasing interdependence, peace, progress and 
freedom are common and indivisible. Consequently, the development of developing countries will benefit the developed countries as well. Developing countries reiterate that the primary responsibility for their development rests on them. Developing countries are determined to contribute to one another's development. (GROUP OF 77, 1967, s/p).

According to Amin (2009; 2010), there was strong resistance from the Western powers against this non-alignment movement and its project of "development ideology" ${ }^{4}$ due to a scenario of global economic crisis that was already unfolding since the late 1960s. From then on, a deep and widespread crisis of the current model of capitalist accumulation is perceived. This economic recession crystallizes in the rising structural unemployment of the welfare society, the Keynesian model of the state, as a driver of the economy and the reshaping of work organization techniques.

In short, the economic and financial crisis of 1970 sparks the end of the conversion of the dollar-gold parity, the inefficiency of the Fordist model, the growing functioning of the parallel financial market that bypassed national regulations, the volatility of paper capitalism. government bonds, foreign exchange) and, mainly, with the breakdown and liquidation of the Bretton Woods System.

Following a period of uncertainty in the international monetary system, US hegemony,

\footnotetext{
4 "Ideology of Development" is defined by the following elements: 1) the desire to develop productive forces, to diversify production, i.e. industrializing; 2) the desire to assure the national state the direction and control of the process; 3) the certainty that "technical" models constitute "neutral" data that can only be reproduced by mastering them; 4) the certainty that the process does not imply a popular initiative, but only its support for state actions; 5) the certainty that the process is not fundamentally contradictory to participation in the changes at the center of the world capitalist system, even if it provokes momentary conflicts with it (AMIN, 2010).
}

according to Wallerstein (2004), began to show signs of decline due to its inflationary crisis, the Vietnam War, and the first oil shock, thus exposing the limits. of US power 5 . Outside the UN, established in 1961, the Kuwait Fund for Arab Economic Development was the first of its kind created by a developing country.

Thus, in 1970, the Islamic Development Bank and the Arab Bank for Economic Development would be created. These initiatives, in terms of financial cooperation in Africa and the Middle East, are at the center of what was the first oil shock in 1974. Essential to this, the creation of the Organization of Petroleum Producing and Exporting Countries (OPEC) It is seen as an expression of South-South Cooperation of collective bargaining from the South to industrialized countries (LEITE, 2012). It is important to note that the price increase was beneficial for some Third World countries, given the transfer of large revenues by oil producing countries as a way of lending to low income countries.

In this context, the member countries of the Non-Aligned Movement in 1973 present the Algiers Charter, in which they oppose any conflicts with regard to Third World regions. That said, in relation to the Southeast Asian region, the Charter celebrates the Paris Accords which it considers a victory for the peo-

\footnotetext{
5 One of the greatest military defeats in the United States, the Vietnam War, began periods earlier with logistical support and founding given to the French in the 1950s. This involvement is explained by the USA's need for permanent expansion of their world hegemonic power, and by the rejection any type of regional threat (FIORI, 2004). However, the defeat in Vietnam did not just mean "a military defeat, or a stain of the United States' prestige. The war dealt a severe blow to the United States' ability to continue to be the world's dominant economic power" (WALLERSTEIN, 2004, p. 26). Costs were high, and the conflict depleted American gold reserves, leading to a scenario in which Western Europe and Japan were experiencing strong economic upturns.
} 
ple of Vietnam, condemning US interference and inviting other nations to help rebuild the Vietnamese state. Thereafter, there is the 1973 Algiers Conference which establishes, one year later, the Declaration of Establishment of a New World Economic Order by the General Assembly.

The Declaration of the Establishment of a New World Economic Order, as a set of proposals mainly from Third World countries, had as its main objective to expand UN institutions to developing countries and also to achieve reform in the International Monetary Fund (IMF). Then begins the theoretical development of the concept of South-South Cooperation, to later institutionalize it within the Organization. The evolution of relations between developing countries is becoming increasingly institutionalized by the UN, thus mechanisms such as the Non-Aligned Movement become only forums for dialogues and ideological manifestations.

On the other hand, with the end of the trade embargo on China and its acceptance with the United Nations, China's export-oriented growth model is emerging on the international stage. Following the defeat in the Vietnam War, the United States decided to approach China by applying to China the same "development by invitation" strategy offered to Germany, Japan, and South Korea. The weaknesses faced by those in the 1970s, these were crucial conditions that favored their approach, known as "ping pong diplomacy" due to the use of sport to resume communication between the two nations (CARVALHO; CATERMOL, 2015).

However, this rapprochement was due to the US interest in strengthening its global hegemony, affected by the political and economic crises. That said, China gradually took a cen- tral role in the global strategy of transnational corporations until it became the 'factory of the world' (CISEKI, 2012, p. 72). As a reaction to this approach, the USSR sought to achieve its influence in the Third World by unleashing fourteen revolutions or sudden regime changes in just a decade, all unfavorable to the US that would widen the strategic imbalance (WALLERSTEIN, 2004).

However, it is clear that in addition to the global economic crisis and the tension of the Cold War, the 1970s were marked by the consolidation and establishment of an agenda on the periphery and "[...] the international insertion of a third bloc in the international order of the Cold War, contributing to the decline of North American hegemony" (PEREIRA, MEDEIROS, 2015, p. 16). As a political force on the world stage, the Third World expressed itself through the Movement of Non-Aligned Countries and the UN. The performance of specialized organisms in the socioeconomic, cultural and health area linked to the United Nations Development Program (UNDP) - of great importance for developing countries - started to cease to represent a support for the policy of the United States (VISENTINI, PEREIRA, 2012). In 1978, a meeting was held in Argentina through UNCTAD between 138 countries that strengthened the concept of South-South Cooperation, culminating in a Plan of Action of Buenos Aires (PABA). In this document, the term "horizontal cooperation" stands out with regard to technical cooperation between developing countries. Brazil is then designated as responsible for promoting the expansion of this activity, which at first became an important foreign policy and international projection tool (UNOSSC, 2016). 


\section{Neoliberal crisis and the recovery of developing economies: the scenario of the resurgence of South- South Cooperation and BRICS conform}

In the face of the rise of a Southern culture, and especially its economic recession, the United States has as a conservative reaction the promotion of neoliberalism as an economic and political doctrine, shaped by a new international strategy to maintain its global hegemony. The American neoliberals, represented by President Reagan (1980-1988), aimed to stop hyperinflation, in addition to the state crisis produced by Fordism and interventionism. To this end, they accused the excessive power of the unions, workers' movements and state social spending as responsible for triggering this recession. In political terms, there is the emergence of a more radical liberalism, under the guise of neoliberalism (FIORI, 2004).

The 1980s were marked by the expansion of neoliberalism to other western capitalist nations. Market deregulation, privatization of domestic companies, and increased international competitiveness immediately became the overriding objectives of the economic policies adopted by these countries.

Given this, Third World countries are politically pressured to adopt neoliberal doctrine. This pressure on Third World countries is marked by the 1988 Washington Consensus, which sought to guide peripheral governments to adopt neoliberal economic reforms to the detriment of their large debts and economic downturn. According to Bresser-Pereira (1991), Washington's approach to Third World countries, notably Latin America, was that ex- cessive state growth, translated into protectionism (the import substitution model), deficit growth public, excess of state-owned enterprises, among other aspects corresponding to the developmental model present in that group of countries, would be the causes of the economic stagnation that plagued those nations in the 1980s. Santos (1999) describes that with no alternatives and in the context of the end of the Cold War with the imminence of possible US unipolarity, neoliberalism began to rise as economic and political doctrine in many developing nations.

It is understood that the political and economic prescriptions issued by the United States, as referred to in the Washington Consensus, were enforced in developing nations internationally through the use of IMF and World Bank credit conditions and structural adjustment packages. Most nations that followed the advice of the IMF have experienced profound economic crises, with rising foreign debt and economic stagnation that perpetuated systemic poverty (BEDER, 2009).

In addition to this economic conjuncture, during the 1980s, peripheral countries faced an obstacle to the promotion of collective action. Thus, the heterogeneity of the group is reflected in the lack of consonance of external action of some countries, regarding the support to the consolidation of an international agenda of developing countries. That said, semiperipheral countries such as China, India, and Brazil began to operate within the bipolar logic of the Cold War, moving away from the idea of positioning themselves as Third World leaders. China, by establishing an alliance with the United States in order to promote the growth of its economy, then contributes to the US venture by counteracting the power of the Soviet Union. 
Furthermore, even with the advances at the multilateral level of technical and economic cooperation, at that time, limitations remained associated to the effectiveness of South-South Cooperation to become a strategy to redefine the international division of labor and industrialization. Physical, technological, institutional and financial barriers were also impediments for these Third World countries to meet mutual demands for intermediate and capital goods. In addition, these challenges became more profound in the 1980s with the economic recession that some Latin American and African countries experienced (LEITE, 2012). In the 1980s and 1990s, therefore, there was a demobilization phase of South-South Cooperation by Third World countries ${ }^{6}$.

The reason for this decline was due to the foreign debt crisis of those countries accompanied by the retraction of the participation of Latin American governments, in a process of democratic transition, on the international stage. Likewise, the replacement of the national developmentalist model by the neoliberal model led the countries of the South to compete with each other in order to receive Foreign Direct Investment (LEITE, 2012). Thus, with the abandonment of the concept of the State as an engine for development, a process of more than decades of joint mobilization was interrupted by the countries of the South.

With glasnost and perestroika, the democratizing, anti-bureaucratic and anti-statist movement in Eastern Europe and the Soviet Union

6 During this period, neither important cooperation actions between developing countries nor events with great relevance for the region were registered, with the exception of the United Nations High Level Conference on Technical Cooperation between Developing Countries in the city of Caracas in 1981 (SANTOS; CERQUEIRA, 2015).
(USSR) ended up being influenced by neoliberal doctrine. From then on, in the late 1980s and early 1990s, the Cold War ended with the dissolution of the USSR and the fall of the Berlin Wall (1991) (SANTOS, 1999; VISENTINI; PEREIRA, 2012). The existence of the Third World movement becomes questionable since its search for autonomy in the face of bipolar dispute, a central issue of the Third World concept, ceases to exist with the emergence of a new configuration of the international system.

Only in the late 1990s and early 2000s did the South-South Cooperation movement resurface as a reflection of dissatisfaction with the social impacts of neoliberal structural adjustment programs and the emergence of progressive governments in several Southern countries. The economic recovery of many of these countries, as a result of the investment opportunities that these markets offered, has helped to strengthen these relationships and, above all, to question the neoliberal development model (LEITE, 2012; LIMA, 2005).

In this context, the East Asian region is experiencing a period of economic miracle. The countries of the former Soviet Union, especially Russia, in the face of the recovery of their national stability, now attract large volumes of international capital through foreign investment. Latin America, after the rise of progressive governments manages to revive its economy, especially Brazil. However, African countries, forced by foreign debt to continue adopting neoliberal adjustments, were largely ignored in the discussions of emerging market-associated investment groups except South Africa (KLAK; JACKIEWICZ, 2002).

As a result, the emergence of new poles of power ultimately influences a change in the balance of power, thereby implying the creation of 
new political arrangements. Notes to this scenario, recurring financial crises in the face of impending neoliberal failure, the emergence of new economic focus, especially China, in contrast to the decline of the epicenter of the world system, as the United States and Europe, among other processes (PAUTASSO; IANKOWSKI, 2013).

The beginning of the crisis of neoliberalism has as its main factor responsible the excess of credit, namely the "excess liquidity", in the early years of the 21st century. This excess credit in the international market, according to Silva (2010), arises as a result of the increasing freedom given to banks by the supervisory agencies to carry out operations in a manner convenient to them.

By the early 2000s, it was becoming clear to developing country governments that the neoliberal matrix was in crisis and reorientation. Although, without resuming the Third World discourse, there was a commitment on the part of these countries to recover the idea that the international system is conditioned by asymmetries that lead to an unequal distribution of power, especially in trade negotiations. This criticism of asymmetric globalization is materialized in the return of a new political matrix with "neo-developmentalist" contours (SILVA, 2009).

This new phase of South-South Cooperation is marked by the efforts of developing countries to seek alternative development models and the emergence of coalitions, such as the India, Brazil and South Africa Dialogue Forum (IBSA) in 2003, and the ASA (South America - Africa) and ASPA (South America Arab Countries) bi-regional summits. The convention of the economic group Brazil, Russia, India, China and South Africa (BRICS) is after the formation of IBSA, ASA and ASPA, but follows the same principles, that is, it comes rather to complement global governance than to compete with her.

Therefore, the new structure of the capitalist system, with the inclusion of developing countries within the international political economy by UN agencies, emerges as a propitious scenario for the creation of the BRICS. Despite the remarkable regional influence of these countries, conceiving the group decades earlier seemed unfeasible, given the internal difficulties faced by each country and the political and economic order imposed by the US and the other European powers, the hard core of economic power. As regional powers, BRICS countries are now making efforts to achieve reforms in international financial and political institutions.

\section{Conclusion}

The liberal doctrine, present in British imperialism, encompassed a set of ideas and assumptions that legitimized, by the European powers, the exploitation, colonization and marginalization of countries with economies and state structures in the early stages of organization. Since then, the main capitalist nations have determined the market position in which the group of peripheral countries should occupy internationally. In this sense, there is a kind of dominance and dependence on those undeveloped countries, precisely because of their specialization in commodity exports. During the twentieth century, the growing expansion and universalization of capitalism projected a scenario of asymmetric globalization in which the system of states began to present greater polarization and economic inequality.

Trotsky's theory of uneven and combined development offers support in explaining one 
of the facets of asymmetric capitalist globalization in addressing the economic and social contradictions of the peripheral or dominated countries. This conception escapes the evolutionary view that shows history as a succession of rigidly predetermined stages, drawing a dialectical view of historical development through sudden leaps and contradictory mergers. According to Löwy (1995), one of the consequences of uneven development is the privilege of latecomers, that is, those who arrive later, named as marginal or peripheral may become the forefront of the next transformation. Previously, Trotsky (1932) develops evidence of this latecomers' thinking of privilege based on the case of France (1789), Russia (1917), and China (1927). Through this latter country the theory dissociates itself from Eurocentrism, accepting the possibility that developing countries from any region of the world could participate in the forefront of the historical movement. There was no development of these hypotheses of international avant-garde beyond China and Russia after Trotsky's work, but it can be inferred that the emergence of the BRICS in the 21 st century context proves that world history is in the process of transformation in which the periphery - or rather, the "Global South" - has increasingly taken up decision-making space in multilateral international institutions concerning global governance.

Despite this finding of BRICS vanguardism in the 21st century, the early period of the periphery's emergence with the Bandung Conference did not receive prominent support from this group of states, which at the time faced internal issues that placed them within the bipolar logic. Cold War With the collapse of the Soviet Union and the end of the Third-Worldist concept, a kind of conservative reaction begins to serve to hinder South-South relations and stren- gthen the periphery in the North-South logic of cooperation. This pro-neoliberal conjuncture is transformed at the beginning of the 21 st century when the beginning of an economic crisis in the capitalist epicenter is evident. It is noted that the concentration of economic growth in countries such as China, Brazil, India and Russia, and the return of criticism to asymmetric globalization are part of the new context of resurgence of the South-South Cooperation phenomenon.

From this perspective, BRICS conforms to a reformist arrangement of the world order, which aims to reach new solutions and forms of cooperation to deal with problems related to development. From then on, the countries of the semi-periphery, such as Brazil, Russia, India, China and South Africa began to act increasingly in tune with the periphery and with each other, reinforcing South-South Cooperation in the current international conjuncture.

\section{References}

AMIN, Samir. 50 Aniversário da Conferência de Bandung (Entrevista com Samir Amin conduzido por Rémy Herrera). In: Marxismo Revolucionário. 2010. Available at: http://resistir.info/samir/bandung_port.html. Accessed: 10 aug. 2016. AMIN, Samir. GeoPolitics of contemporary Imperialism. Buenos Aires: CLACSO, 2004. Available at: http://biblioteca. clacso.edu.ar/clacso/se/20100613064644/5Amin.pdf. Accessed: 19 aug. 2016.

AMIN, Samir. Sortir de la crise du capitalisme ou sortir du capitalisme en crise? Paris: Le Temps des Cerises, 2009. Available at: http://www.iea-nantes.fr/fichier/j_telechargement/17/ telechargement_fichier_fr_sortir.du.capitalisme.pdf. Accessed: 19 aug. 2016.

BEDER, Sharon. Neoliberalism and the Global Financial Crisis. Social Alternatives, 2009. Available at: http://citeseer. ist.psu.edu/viewdoc/summary?doi=10.1.1.683.9454. Accessed: 10 aug. 2016.

BRESSER-PEREIRA, Luiz Carlos. A crise da América Latina: Consenso de Washington ou crise fiscal? Pesquisa e Planejamento Econômico, 1991. Available at: http://www. bresserpereira.org.br/papers/1991/91-acriseamericalatina.pdf. Accessed: 10 aug. 2016. 
CARVALHO, Cecília; CATERMOL, Fabrício. As Relaçóes Econômicas entre China e EUA: Resgate Histórico e Implicaçóes. Rio de Janeiro: Revista do BNDES, 2009. Available at: http://www.bndespar.gov.br/SiteBNDES/export/sites/default/ bndes_pt/Galerias/Arquivos/conhecimento/revista/rev3108. pdf. Accessed: 23 aug. 2016.

CISESKI, Pedro Paulo. China: Milagre econômico e desafios pós-crise financeira internacional. IPEA, 2012. Available at: http://repositorio.ipea.gov.br/bitstream/11058/4553/1/BEPI_ n10_china.pdf Accessed: 10 aug. 2016.

EICHENGREEN, Barry. A globalizaçáo do capital: uma história do Sistema Internacional. Brasil: EDITORA 34, 2002.

FIORI, José Luis. O Poder Global dos Estados Unidos: formação, expansão e limites. Poder Global, 2004. Available at: http://www.poderglobal.net/wp-content/uploads/2015/08/ CAPITUALO-ESTADOS-UNIDOS-FIORI.pdf. Accessed: 20 aug. 2016.

GRUPO DOS 77. First Ministerial Meeting Of The Group Of 77: Charter Of Algiers. Genebra, 1967. Available at: http:// www.g77.org/doc/algier $\sim$ 1.htm. Accessed: 10 aug. 2016.

KLAK, Thomas; JACKIEWICZ, Edward. What has happened to social development policy in the era of neoliberal globalization and emerging markets? A look at latin america in global context. Revista de Ciência Política, n. 1, p. 112 - 129, 2002. Available at?: http://citeseer.ist.psu.edu/viewdoc/download?doi=10.1.1.453.6107\&rep=rep1\&type=pdf. Accessed: 10 aug. 2016.

KOCHER, Bernardo. O Brasil no Terceiro Mundo. Análise da política externa brasileira entre 1955 e 1964 . Rio de Janeiro, 2008. Available at: http://encontro2008.rj.anpuh.org/resources/content/anais/1215426824_ARQUIVO_KOCHER_ ANPUH-RIO_2008.pdf. Accessed: 17 aug. 2016.

LEITE, Iara Costa. Cooperaçáo Sul-Sul: Conceito, História e Marcos Interpretativos. Rio de Janeiro: Observatório Político Sul-Americano, 2012. Available at: http://observatorio.iesp. uerj.br/images/pdf/observador/observador_v_7_n_03_2012. pdf. Accessed: 20 aug. 2016.

LIMA, Maria Regina Soares de. A política externa brasileira e os desafios da cooperaçáo Sul-Sul. Brasília: Revista Brasileira de Política Internacional, 2005.

LÖWY, Michael. A teoria do desenvolvimento desigual e combinado. 1995. Available at: http://www.afoiceeomartelo. com.br/posfsa/Autores/Lowy,\%20Michael/a\%20teoria\%20 do $\% 20$ desenvolvimento $\% 20$ desigual $\% 20 \mathrm{e} \% 20$ combinado. pdf. Accessed: 10 aug. 2016.

PAUTASSO, Diego; IANKOWSKI, Bruno. O Ibas como expressáo das coalizóes Sul-Sul: o caso do fundo para alívio da fome e da pobreza. Porto Alegre: ESPM, 2013.
PEREIRA, Analúcia Danilevicz; MEDEIROS, Klei. O prelúdio da Cooperaçáo Sul-Sul: da Conferência de Bandung à Conferência de Buenos Aires (1955-1978). Porto Alegre: UFRGS, 2015.

SANTOS, Theotonio dos. O neoliberalismo como doutrina econômica. Revista Econômica UFF, 1999. Available at: http://www.uff.br/revistaeconomica/v1n1/theotonio. Accessed: 10 aug. 2016.

SANTOS, Roberta de Freitas; CERQUEIRA, Mateus Rodrigues. Cooperaçáo Sul-Sul: experiências brasileiras na América do Sul e na África. Rio de Janeiro: História, Ciência, Saúde - Manguinhos, 2015. Available at: www.scielo.br/pdf/ hcsm/v22n1/pt_0104-5970-hcsm-22-01-00023.pdf. Accessed: 10 aug. 2016.

SAUVY, Alfred. Trois mondes, une planète. Paris: L'Observateur, 1952. Available at: http://www.homme-moderne.org/ societe/demo/sauvy/3mondes.html. Accessed: 10 aug. 2016.

SILVA, Andre Luis Reis da. Do otimismo liberal a globalizaçáo assimétrica: a política externa do Governo Fernando Henrique Carsoso (1955-2002). Curitiba: Jurua, 2009.

SILVA, Bruno Mattos. A desregulamentaçáo dos mercados financeiros e a crise global: liçôes e perspectivas. Brasília: Senatus, 2010.

THEIS, Ivo Marcos. Do desenvolvimento desigual e combinado ao desenvolvimento geográfico desigual. Belém: NAEA, 2009. Available at: http://www.periodicos.ufpa.br/ index.php/ncn/article/view/324/510. Accessed: 10 aug. 2016.

TOMLINSON, Brian R.. What Was the Third World? London: Journal of Contemporary History, 2003. Available at: https://www.jstor.org/stable/3180660?seq=1\#page_scan_tab_ contents. Accessed: 10 aug. 2016.

TROTSKY, Leon. The History of the Russian Revolution. Library of Congress, 1932.

UNOSSC. (United Nations Office for South-South Cooperation). What Is South-South Cooperation? 2016. Available at: http://ssc.undp.org/content/ssc.html. Accessed: 10 aug. 2016.

UWEC (University of Wisconsin-Eau Claire). Three-World Model. 2016. Disponível em http://people.uwec.edu/ivogeler/ w111/3world.htm. Accessed: 05 aug. 2016.

VISENTINI, Paulo Fagundes; PEREIRA, Analúcia Danilevicz. Manual do Candidato: História Mundial Contemporânea (1776-1991) Da independência dos Estados Unidos ao colapso da União Soviética. Brasília: FUNAG, 2012.

WALLERSTEIN, Immanuel Maurice. O declínio do poder americano: os Estados Unidos em mundo caótico. Rio de Janeiro: Contraponto, 2004. 